\title{
Perbandingan Tata Kelola Penanganan Pandemi Covid 19 di Indonesia dan India
}

\author{
Nisa Khoerunisa ${ }^{1}$ dan Faisal Fadilla Noorikhsan ${ }^{1^{*}}$ \\ ${ }^{1}$ Jurusan Ilmu Politik, Universitas Siliwangi, 46115, Tasikmalaya-Indonesia
}

\begin{tabular}{l}
\hline \hline Info Artikel \\
\hline Dikirim: Okt 19, 2020 \\
Diterima: Jan 27, 2021 \\
Dipublikasi: Jan 31, 2021 \\
\hline
\end{tabular}

Kata Kunci:

Covid 19;

Kebijakan;

Lockdown;

PSBB;

Koresponden:

Faisal Fadilla Noorikhsan

Jurusan Ilmu Politik

Universitas Siliwangi

Email:

faisal.fadilla@unsil.ac.id

\section{Sitasi Cantuman:}

Khoerunisa, N. \& Noorikhsan, F. F. (2021). Perbandingan Tata Kelola Penanganan Pandemi Covid 19 di Indonesia dan India. Journal of Political Issues. 2(2); 89-101. https://doi.org/10.33019/jpi.v2i 2.36

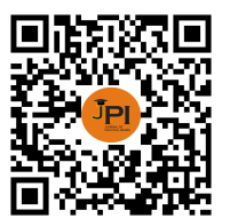

DOI:

https://doi.org/10.33019/jpi.v2i 2.36

\section{ABSTRAK}

Abstract This paper tries to compare the governance of handling the Coronavirus Diseases (Covid 19) pandemic in Indonesia and India. Although it had implemented a total lockdown until September the number of positive cases of COVID-19 in India reached more than 4.7 million with a death toll of more than 78 thousand people. Meanwhile, Indonesia has never recorded a total lockdown. The result is no better than India. Throughout September, seven times the record positive addition of Covid 19 broke. We try to do the best government policy analysis among the worst. This paper is made from qualitative research, namely research aimed at generating knowledge in a coherent way. Using the literature method, collecting as much information from print and electronic media related to COVID 19 in Indonesia and India, we analyzed the policies of the governments of the two countries. This paper recommends a thorough evaluation of the Indonesian government's policy in handling covid 19. Indonesia now tops the statistics on the number of deaths due to COVID-19 in Southeast Asia.

Abstrak Tulisan ini mencoba membandingkan tata kelola penanganan pandemi Coronavirus Diseases (Covid 19) di Indonesia dan India. Meskipun sempat menerapkan lockdown total sampai bulan September jumlah kasus positif COVID-19 di India tembus lebih dari 4,7 juta dengan angka kematian lebih dari 78 ribu jiwa. Sementara itu, Indonesia tak pernah tercatat melakukan lockdown total. Hasilnya tidak lebih baik dari India. Sepanjang bulan September tercatat tujuh kali rekor penambahan positif Covid 19 pecah. Kami coba melakukan analisis kebijakan pemerintah terbaik di antara yang terburuk. Tulisan ini dibuat dari penelitian kualitatif yakni penelitian yang ditujukan untuk menghasilkan pengetahuan dengan cara koheren. Dengan menggunakan metode kepustakaan, mengumpulkan sebanyak mungkin informasi dari media cetak dan elektronik terkait covid 19 di Indonesia dan India, kami menganalisis kebijakan pemerintah kedua negara tersebut. Tulisan ini merekomendasikan evaluasi menyeluruh terhadap kebijakan pemerintah Indonesia dalam penanganan covid 19. Pasalnya, kini Indonesia menduduki posisi teratas statistik jumlah kematian akibat COVID-19 di Asia Tenggara.

\section{Tentang:}

Nisa Khoerunisa, menyelesaikan Pendidikan S2 pada jurusan Magister Ilmu politik Universitas Padjajaran dan sekarang ini menjadi dosen tetap pada jurusan Ilmu Politik Universitas Siliwangi Tasikmalaya.

Faisal Fadilla Noorikhsan, menyelesaikan pendidikan S2 pada jurusan Magister Ilmu Politik Universitas Diponegoro Semarang tahun 2016. Saat ini menjadi dosen tetap pada jurusan Ilmu Politik Universitas Siliwangi Tasikmalaya

Lisensi:

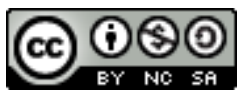

Attribution-NonCommercialShareAlike 4.0 International (CC- BY-NC-SA 4.0)

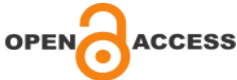




\section{PENDAHULUAN}

Pandemi Covid 19 merupakan salah satu pandemi dalam sejarah kontemporer. Di tengah globalisasi yang makin dalam dan masifnya perkembangan teknologi informasi, pandemi ini menghadirkan tentangan yang lebih besar dan kompleks. Kajian yang muncul sesaat setelah Covid 19 dinyatakan muncul adalah dampaknya terhadap ekonomi politik global dan domestik. Jika pandemi-pendemi sebelumnya menular melalui perantara binatang atau interaksi khusus antar manusia, Covid 19 memiliki karakter yang menular langsung antarmanusia (Shereen dkk., 2020).

Pemerintah dibanyak negara dihadapkan pada situasi membingungkan saat wabah covid 19 muncul. Mereka dipaksa mengambil langkah-langkah strategis guna menangani dan merespon keadaan pandemi. Masing-masing negara menunjukkan kesiapan yang berbedabeda. Pandemi Covid 19 juga telah menunjukan baik buruknya tata kelola dan kebijakan pemerintah suatu negara. Pada awalnya pemerintah Indonesia menunjukkan kegagapan dan terjebak dalam penyangkalan atas tingkat urgensi maupun dampak covid 19 sebelum akhirnya mengambil langkah-langkah yang dibutuhkan untuk menangani pandemi secara lebih sistematis. (Mas'udi \& Winarti 2020)

Sementara itu, India dengan populasi penduduk lebih dari 1,3 milyar mencatatkan angka kasus positif COVID-19 yang semakin meningkat. Pada bulan Juli (07/2020), satu bulan setelah lockdown dilonggarkan, India menjadi negara ketiga dengan kasus covid-19 terbanyak di dunia setelah Amerika Serikat dan Brasil. Kasus melaju pesat dengan penambahan lebih dari 20.000 kasus terkonfimasi setiap harinya. (BBC NEWS Indonesia, 2020). Terlepas dari kemajuan teknologi serta pelayanan kesehatan, pandemi membuat pemerintah mengambil kebijakan yang cenderung bersifat trial and error, yang berdampak pada keberlangsungan kehidupan warga negaranya.

Berbagai pendekatan menghadapi pandemi Covid 19 tidak terlepas dari pengaruh sistem politik, kultur dan gaya pemimpin negara masing-masing. Misalnya saja Korea Selatan yang memilih menggunakan tracing seluas mungkin, India dengan memilih lockdown, atau penggunaan PSBB yang dilakukan oleh Indonesia. Di Jepang, sekolah dan perguruan tinggi ditutup mulai pertengahan maret 2020. Penutupan tersebut membuat sekitar 13 juta murid dan mahasiswa di seluruh Jepang harus tinggal di rumah masing-masing, menghentikan semua program perkuliahan tatap muka, dan program-program magang di perusahaan (Davidson, Kuo dan McCurry, 2020). Pemerintah Vietnam, Laos, India, Srilanka, dan Malaysia memutuskan menutup semua kegiatan pendidikan sejak awal maret 2020

Pandemi juga menimbulkan issu baru terkait keberlangsungan sistem politik mana yang paling relevan dan berhasil menangani krisis demi peradaban hidup manusia. Ilmuan politik kembali menggulirkan perdebatan mengenai tipe rezim, demokratis vs otoriter, dan juga pilihan kebijakan pemerintah mana yang efektif, lockdown vs bukan lockdown. Baik Indonesia maupun India adalah negara di benua Asia yang masuk dalam kajian Global Democracy Ranking dengan posisi yang tidak jauh berbeda. Menurut Global Democracy, pada tahun 2015 Indonesia menempati peringkat ke 68, sedangkan India jauh lebih baik 3 tingkat yakni berada diurutan 65 (Global Democracy Ranking, 2015). Indonesia dan India dikategorikan sebagai developmental democratic state atau negara demokrasi yang sedang mengalami transisi. Keduanya memiliki persamaaan secara demografis dan historis yang membuat civil society dan proses demokratisasi diantara keduanya memiliki persamaan. Salah satunya adalah bermunculannya fenomena uncivil society (atau civil society yang sakit). Hal ini ditandai misalnya dengan bermunculan kelompok dengan membawa politik identitas tertentu dengan menggunakan kampanye kekerasan dalam gerakannya. (Muradi, 2016).

Tulisan ini mencoba membandingkan sejauh mana efektivitas tata kelola pandemi Covid 19 didua negara, yaitu Indonesia dan India. Sebagai negara yang sama-sama terkena dampak Covid-19, India memberlakukan lockdown total sebagai pilihan kebijakan yang 
diambil oleh pemerintah, sedangkan Indonesia menerapkan Pembatasan Sosial Berskala Besar (PSBB) selama tiga bulan, mulai dari pertengahan bulan Maret sampai Juni 2020. Menurut laporan Knowledge Group yang dimuat di laman Forbes, Indonesia masuk kategori 20 negara dengan tingkat safety serangan virus paling rendah, dengan risiko-risiko penularan paling tinggi. Dalam hal safety yang diukur dari aspek kebijakan berkaitan dengan quarantine efficiency, government management efficiency, monitoring and detection, dan emergency treatment readiness, Indonesia berada dalam lima negara dengan tingkat keamanan terbawah, bersama India, Srilanka, Myanmar, Kamboja, dan Laos (Colangelo, 2020)

Sebagai negara dengan populasi terbanyak didunia, baik India maupun Indonesia berhadapan dengan persoalan besar saat WHO menetapkan status Coronavirus Disease (covid-19) sebagai pandemi. Penyakit yang sudah menginfeksi lebih dari 110 negara ini disikapi dengan respon yang berbeda. Beragam pilihan sikap tersebut dinilai berhasil jika mampu menahan laju penyebaran dan rendahnya angka kematian yang disebabkan oleh covid-19. Kontrol pemerintah dan kebijakan yang responsif tersebut bukan hanya menyoal pengendalian angka fatalitas namun juga keberlangsungan hidup warganya secara umum. Dengan melihat pengamanan India yang memilih retriksi total (lockdown), lalu Indonesia dengan pembatasan sosial berskala besar (PSBB), tulisan ini bermaksud melihat efektivitas pilihan yang diambil oleh keduanya. Mekanisme pengambilan keputusan yang dilakukan oleh para pemangku kebijakan paling berperan dalam menekan laju penyebaran covid. Tujuan utama tulisan ini adalah sebagai studi awal respon negara terhadap penanganan Covid-19 dari perspektif efektivitas kebijakan. Artikel ini selanjutnya akan memetakan pendekatan yang dilakukan oleh Indonesia dan India untuk mengelola pandemi serta membandingkan efektivitas keberhasilan diantara kebijakan lockdown dengan PSBB. Berikutnya rumusan masalah yang akan dijawab adalah "Bagaimana Indonesia dan India mengelola krisis pandemi? Sejauh apa keberhasilan kebijakan lockdown di India dan PSBB di Indonesia mengatasi krisis pandemi?"

\section{METODE PENELITIAN}

Rancang penelitian yang digunakan oeh penulis adalah studi perbandingan (comparative study or casual comparative study). Jenis tulisan ini mengacu pada bentuk penelitian deskriptif yang membandingkan dua atau lebih dari situasi, kejadian, kegiatan, program dll, yang sejenis atau sama. (Syaodih, 2007) Tulisan dalam penelitian menggunakan metode kepustakaan. Adapun metode ini digunakan karena secara bibliografis berguna untuk menyusun kembali informasi empiris yang menjadi tema penulisan. Selain karena fungsinya sebagai membantu secara bibliografis, metode ini tepat digunakan untuk sebagai alternatif untuk mensiasati keterbatasan penulis untuk terjun langsung ke lapangan.

Teknik pengumpulan data dalam studi ini adalah dengan menggunakan metode studi literatur. Berbagai data sekunder di antaranya: artikel-artikel media massa, cetak maupun online terkait pandemi Covid-19 dengan berfokus mengkaji di dua negara, yaitu Indonesia dan India. Penulis memilih kedua Negara tersebut karena masing-masing dapat merepresentasikan kebijakan penanganan pandemi yang berbeda. Sumber-sumber lain dalam bentuk rekaman vidio menjadi data penunjang penelitian untuk memahami lebih jauh pandemi Covid-19, respon negara terdampak, dan dampaknya terhadap sosial-poitik. Datadata yang ada penulis olah dengan menggunakan pendekatan critical reading.

\section{HASIL PENELITIAN \\ Pandemi Yang Mengguncang Dunia}

Bermula dari kota Wuhan, China, virus varian baru yang kemudian diidentifikasi sebagai SARS Cov-2 menjadi bencana yang mewabah di seluruh negara di dunia. Respon negara dalam menghadapi pandemi Covid-19 beragam. Suatu negara dikatakan tanggap dalam 
penanganan pandemi apabila terdapat kepemimpinan yang kuat yang direspon solid oleh rakyatnya. Kesiapsiagaan suatu negara juga ditentukan dari seberapa mampu menekan laju penyebaran, tingkat fatalitas, kemampuan menangani pasien terinfeksi, serta dilihat dari kapasitas mobilisasi dan mengelola sumber daya secara tepat untuk menangani krisis beserta dampaknya. Kebijakan yang bersifat komprehensif juga mencakup keseluruhan siklus situasi krisis, mulai tanggap darurat, penanganan dampak sosial-ekonomi. Untuk menanggulangi perkembangan virus tersebut, berbagai cara ditempuh oleh negara agar dapat menjamin keberlangsungan hidup warga negaranya.

Penanganan Covid-19 dan dampaknya, membutuhkan kapasitas sumber daya yang sangat besar. Di beberapa negara bisa disaksikan pengerahan sumber daya yang luar biasa besar, baik untuk menangani wabah maupun untuk menyelamatkan ekonomi dan kehidupan sehari-hari masyarakat dengan berbagai bentuk subsidi ekonomi dan jaring pengaman sosial. Gerak cepat yang dilakukan oleh tiap negara dalam merespon covid-19 sangat menentukan bukan hanya laju angka perkembangan covid-19, tetapi juga gerak roda perekonomian warga negaranya. Sebagaimana halnya dengan negara-negara lain yang terdampak, Indonesia melakukan berbagai upaya agar penyebaran virus bisa ditekan semaksimal mungkin. Luasnya wilayah Indonesia, dengan jumlah populasi yang tidak sedikit membuat pemerintah Indonesia secara bertahap memberlakukan pembatasan aktivitas serta penutupan akses wilayah. Pilihan bersebrangan dilakukan oleh India yang secara mendadak melakukan retriksi total.

Indonesia adalah negara dengan populasi terbesar di Asia Tenggara. Begitu juga dengan India, sebagai peringkat pertama terpadat di Asia Selatan. Kondisi tersebut menimbulkan kekhawatiran dari pihak WHO yang menilai jika kedua negara tersebut dapat menjadi episenter baru. Senior Advisor on gender and Youth to the WHO, Diah Saminarsih mengatakan jika kedua negara ini tidak dapat mengontrol epidemi, maka Kawasan Asia Tenggara menjadi episenter di dunia, menggeser Amerika dan Eropa (Nursastri, 2020). Hal tersebut menjadi tantangan besar bagi pemerintah masing-masing negara dalam memformulasikan kebijakan yang dibuat.

Selain itu, pengelolaan pandemi Covid 19 menghadapi tantangan karena mobilitas manusia masa kini yang sangat tinggi. Covid 19 juga berkembang ketika populisme (kepemimpinan politik nasionalis dan sikap anti-science) semakin meluas dalam politik domestik banyak negara. Situasi dimana seharusnya pemerintah mengambil kebijakan rasional yang sifatnya jangka panjang, tergantikan oleh langkah politik dan kebijakan berorientasi popularitas jangka pendek dan berorientasi kepentingan untuk memperkokoh kekuasaan (Kluth, 2020). Karakter pandemi ini dijadikan komoditas politik personal atau kelompok, dengan mengorbankan esensi penanganan krisis, yaitu kemanusiaan.

\section{Semrawut Lockdown India Atasi Krisis Pandemi}

India adalah negara besar dengan populasi penduduk yang padat dan mengalami kasus Covid-19 tercatat sebanyak 1.116.597 hingga 19 Juli 2020 (HT Correspondent, 2020). Kasus Covid-19 pertama kali didokumentasikan pada tanggal 30 Januari 2020, yang mana adalah warga India yang dievakuasi dari China. (Laxminarayan, dkk, 2020) Dalam menangani covid-19, India menggunakan langkah-langkah pro-aktif yang terdiri dari pengujian agresif yang dilakukan oleh pemerintah pusat yang bekerjasama dengan negara bagian wilayahnya. Jika Indonesia tidak menggunakan langkah lockdown, negara dengan mayoritas beragama Hindu itu berani mengambil langkah untuk mengunci negaranya dalam beberapa tahapan. Negara yang terletak di Kawasan Asia Selatan ini menerapkan kebijakan lockdown, sejak 25 Maret 2020 untuk diberlakukan selama tiga pekan. Skenario tersebut digunakan oleh India untuk melacak orang yang terinfeksi yang akan terlihat gejalanya selama 14 hari, dan satu minggu kemudian dicadangkan untuk mengamati situasi infeksi, kematian dan tingkat pemulihan (Paital, Das, and Parida, 2020) 
Lockdown sendiri membawa konsekuensi bagi diberhentikannya semua aktivitas, baik itu bisnis maupun transportasi publik. Akibatnya, eksodus besar-besaran terjadi di kota besar. Belum seminggu sejak lockdown ditetapkan, India mengalami banyak persoalan. Berbagai persoalan muncul ke permukaan dan berujung krisis kemanusiaan pasca pengumuman Lockdown diberlakukan. Meskipun Pemerintah India mengumumkan bantuan stumulus ekonomi sebesar 260 Milyar kepada rakyatnya, namun dikarenakan tahapan skemanya belum jelas, jutaan pekerja informal dan pekerja migrant kehilangan pekerjaannya. 10 juta pekerja India kesulitan bagaimana mengakses makanan (International Growth Centre, 2020). Penguncian dengan minimalisir persiapan tersebut, selain mengakibatkan jutaan pekerja menganggur, pada akhirnya berdampak pada peningkatan laporan serangan rasis terhadap migran dari India Timur, termasuk dengan kekerasan fisik yang ditangkap dan dibagikan ke media social. (Kikon, 2020)

Kerusuhan terjadi akibat ratusan ribu orang memaksa untuk pulang kampung, kekerasan yang dilakukan oleh aparat marak terjadi, kasus kelaparan pun merajalela. Bahkan, tagar \#ModiMadeDisater sempat menjadi trending topic di twitter. (Adam, 2020). Begitu juga saat kemudian keputusan untuk memperpanjang lockdown dilakukan oleh India hingga 3 Mei 2020. Lockdown yang semula direncanakan berakhir pada 14 April harus mengalami perpanjangan karena Narendra Modi berkeyakinan jika penguncian dan distancing social merupakan cara yang efektif untuk melindungi warganya yang berjumlah 1,3 Miliar.

Pemerintah India lantas memperpanjang lockdown hingga 30 Juni 2020, dengan hanya mengizinkan pembukaan kegiatan ritel, rekreasi dan perbelanjaan secara bertahap (Saha, Barman, and Chouhan, 2020). Pemerintah memberikan keringanan bagi para petani dan pekerja harian dalam pemberlakuan aturan tersebut. Pemerintah India menilai pengorbanan kerugian ekonomi yang harus ditanggung akibat dari lockdown tidak lebih berarti daripada mempertahankan kehidupan warganya. Meskipun banyak menimbulkan persoalan kemanusiaan dan mendapatkan kritikan, lockdown yang diterapkan India selama 45 hari membuahkan hasil yang positif dan diklaim memainkan peranan besar dalam menekan angka penyebaran penyakit. (Bhattacharjee, Kumar, and Patel, 2020). Lockdown yang tepat waktu membuat volume yang terinfeksi covid-19 di India lebih sedikit dibandingkan negara besar lainnya. (Pai, Bhaskar, and Rawoot, 2020) Tindakan penguncian tersebut mendapatkan apresiasi dari WHO karena India sebagai negara terpadat kedua didunia menunjukkan tingkat infeksi dan kematian yang rendah dibandingkan negara lain. Masing-masing yaitu 9.152 dan 306 per 1,3 miliar populasi per/13 April 2020 (Paital, Das, and Parida, 2020). Selain menekan laju penyebaran covid-19, lockdown membawa dampak signifikan bagi kondisi lingkungan dan udara disana. India mengalami proses peremajaan yang ditandai oleh pengurangan polutan yang cukup berbahaya dan berakibat fatal bagi kesehatan manusia (Lal \& Pawar, 2011)

Guna menanggulangi dampak pandemi Covid 19, India menggelontorkan anggaran sebesar US\$2,1 milliar untuk melengkapi fasilitas kesehatan. Dari anggaran tersebut, Departemen Sains dan Tekhnologi Pemerintahan India telah mengajukan skema untuk mempromosikan penelitian dan penemuan di lembaga-lembaga penelitian yang bekerja dalam pengendalian wabah ketika sedang dilakukan lockdown. CSIR atau Dewan Riset Industri India India juga mengalami krisis infodemik dimana hoax Covid-19. India adalah pengguna internet dan media sosial kedua setalah China. Sebagai negara dengan populasi rakyat terbesar kedua di dunia, India menggabungkan berbagai pendekatan dalam mengatasi laju covid-19. Sekalipun menimbulkan efek kemanusiaan, lockdown dianggap membawa dampak signifikan bagi penekanan angka laju Covid-19. Gaya kepemimpjnan dibawah Perdana Menteri Narendra Modi yang tergas menyerukan lockdown dengan keseriusan sejak awal pandemik berkembang. Kesigapan otoritas kesehatan di India melalui proses pelacakan dan pengujian dilakukan guna menekan angka kematian. 
Langkah-langkah strategis yang dilakukan oleh pemerintahan India tersebut tidak bertahan lama. Proses penguncian tersebut selain menimbulkan dampak sosial, berdampak juga pada perputaran roda ekonomi sehingga India mulai melonggarkan kebijakan lockdown. Jika saat penguncian dilakukan selama bulan Maret-Mei kasus terkonsentrasi di kota-kota besar, pelonggaran lockdown berdampak pada mobilisasi penduduk India dari kota ke daerah pedesaan, yang berakibat pada penyebaran kasus Covid-19 di pedesaan. Pilihan kebijakaan untuk melonggarkan lockdown membuat kasus infeksi melonjak kembali dengan tajam. Memasuki bulan Agustus, kasus meningkat dan berkembang dengan cepat sehingga mencapai 75.000 kasus infeksi setiap harinya. Tercatat hingga pekan keempat Agustus (08/2002), India menjadi negara ketiga dengan catatan kematian tertinggi setelah Amerika Serikat dan Brazil dengan angka kematian mencapai 60.000 dan kasus terkonfirmasi sebanyak 3 juta kasus. (Gettleman, \& Yasir, 2020)

\section{Kegagapan Indonesia Hadapi Krisis Pandemi}

Ketika kasus pertama covid-19 terkonfirmasi di Indonesia pada tanggal 2 Maret 2020, secara global kasus terkonfirmasi sudah mencapai 88.948 kasus. Kasus pertama terkonfirmasinya Covid-19 di Indonesia dilaporkan WHO pada "situation report 2", dimana Indonesia tercatat bersama 5 negara lain yaitu Armenia, Czechia, Republik Dominika, Luksemburg, dan Islandia (WHO, 2020). Situasi krisis yang datang tiba-tiba memicu kepanikan semua pihak, baik di level pemerintah pusat maupun pemeirntah daerah serta masyarakat biasa. Dalam kondisi seperti itu pengambil kebijakan dituntut untuk membuat kebijakan yang dapat mereduksi potensi konflik akibat situasi krisis (Ambar \& Mas'udi, 2020)

Seminggu setelah kasus pertama terkonfirmasi dan kasus semakin melonjak, berbagai pihak mulai menggaungkan suara untuk melakukan lockdown (karantina wilayah) seperti yang sudah dicontohkan oleh negara lain seperti Tiongkok. Namun seruan lockdown ini tak membuat pemerintah bergeming. Presiden Joko Widodo memiliki keyakinan bahwa penyebaran Covid 19 bisa dilakukan dengan Physical Distancing. Meskipun pihak IDI menganggap karantina wilayah lebih efektif untuk memutus mata rantai penyebaran covid-19 dibandingkan pemberlakuan PSBB, namun pemberlakuan karantina wilayah tidak diberlakukan oleh Joko Widodo dengan pertimbangan ekonomi, geografis, kultural, dan sosiologis masyarakat Indonesia yang berbeda dengan negara lain yang menerapkan karantina wilayah. Menurut Joko Widodo, karantina wilayah tidak dipilih setelah membandingkan kebijakan tersebut dari negara lainnya yang dinilai tidak menjamin keberhasilan penerapan karantina wilayah tanpa menimbulkan masalah. Menurutnya, tidak ada satu formula yang pasti dalam mengatasi persoalan covid-19 ini. (Najwa Shihab, 2020)

Pemberlakuan kebijakan sosial berskala besar baru ditetapkan oleh Joko Widodo pada akhir Maret sebagai kelanjutan dari pembatasan social distancing dengan menggunakan Peraturan Pemerintah nomor 21 tahun 2020 sebagai dasar peraturan. Kebijakan tersebut diambil karena penambahan kasus yang makin meningkat dari hari ke hari. Juru bicara pemerintah untuk penanganan Covid-19 Achmad Yurianto yang sekaligus menjabat Dirjen Pencegahan dan Pengendalian Penyakit Kemenkes mengatakan jika PSBB dilakukan karena physical distancing yang diabaikan oleh masyarakat. Menurutnya, jika pembatasan sosial tidak mempan, maka akan diberlakukan pembatasan sosial berskala besar. Cara tersebut ditempuh karena diyakini dapat memutus rantai penularan. Ditambahkan olehnya, jaga jarak harus juga dilakukan karena jika hal tersebut gagal dilakukan maka negara akan terancam jebol. (Tempo, 2020)

Indonesia tergolong terlambat merespon situasi krisis. Jika dilihat dari perspektif komunikasi publik, Indonesia sempat melakukan hal gegabah dengan pernyataan-pernyataan simplikatif dari para pejabat publik. Misalnya saja klaim jika Indonesia sebagai satu-satunya negara yang tidak terinfeksi, atau kampanye jamu sebagai penangkal obat (Fakhruroji, dkk, 2020). WHO kemudian memberikan peringatan kepada Indonesia agar segera 
mendeklarasikan darurat nasional Covid-19 melalui surat tertanggal 10 Maret 2020 yang ditujukan kepada Presiden Indonesia, Joko Widodo (Berty, 2020). Dampaknya adalah pemerintah mengeluarkan produk hukum "tahu bulat". Hanya dalam jangka waktu satu bulan, 9 produk hukum terkait penanganan pandemi Covid-19 diterbitkan. Kebijakankebijakan tersebut merupakan respon atas eskalasi masalah ditinjau dari segi kesehatan masyarakat, sosial, administrasi, keuangan, kewenangan dan politik birokrasi pemerintahan.

Untuk menjaga stabilitas keuangan negara akibat krisis pandemi pemerintah Indonesia mengeluarkan Peraturan Pemerintah Pengganti Undang-Undang (Perppu) Nomor 1 tahun 2020 tentang Kebijakan Keuangan Negara dan Stabilitas Sistem Keuangan untuk Penanganan Covid-19 dan dalam rangka menghadapi ancaman yang membahayakan perekonomian nasional dan stabilitas sistem keuangan, tanggal 31 Maret 2020. Perppu ini menjadi landasan hukum bagi penyesuaian anggaran dalam kondisi luar biasa, sekaligus justifikasi penambahan anggaran belanja dan pembiayaan APBN 2020 untuk menangani Covid 19, dengan total tambahan belanja dan pembiayaan APBN tahun 2020 sebesar 405,1 triliun.

Selain itu, Dana sebesar 110 trilyun dialokasikan pemerintah untuk tambahan jaring pengaman social terkait covid-19. Jangkauan program keluarga harapan diperluas dari 9,2 juta penerima menjadi 10 juta penerima dan nilainya ditambah $25 \%$. Peruntukkan kartu sembako yang semula dianggarkan untuk 15,2 juta penerima diperbesar menjadi 20 juta penerima dengan nilai manfaat yang naik dari 150 ribu menjadi 200.000. Kemudian anggaran anggaran kartu prakerja dinaikan dari 10 trilliun menjdi 20 triiliun dengan rincian jumlah penerima. manfaat ditambah dari dua juta orang menjadi 5,6 juta penerima (Kompas, 2020)

Kebijakan Pembatasan Sosial Berskala Besar (PSBB) dilaksanakan setelah terbitnya Peraturan Pemerintah (PP) Nomor 21 tahun 2020, tanggal 31 Maret 2020, tiga minggu setelah kasus pertama diumumkan di Indonesia. PP tersebut mengatur tentang pelaksanaan PSBB dan pemerintah daerah dapat melaksanakannya atas persetujuan Menteri Kesehatan. Dengan jumlah kasus yang telah meningkat dan meluas lintas wilayah kebijakan ini sangat terlambat. Karena PSBB baru dilaksanakan bulan April, dan tidak serentak semua wilayah melaksanakannya.

PSBB di DKI Jakarta sendiri, misalnya, baru diberlakukan pada hari pertengahan April 2020. Kemudian diikuti oleh berbagai kota besar lainnya (Carina, 2020). Meskipun PSBB diberlakukan masyarakat masih diperbolehkan untuk keluar rumah dengan mengikuti mengikuti protokol kesehatan yang telah ditentukan. Penerapan PSBB yang diberlakukan di berbagia daerah tidak serta merta dipatuhi oleh masyarakat. Berbagai pelanggaran masih terjadi dan ditemukan selama penerapan PSBB. Misalnya saja keramaian masih ditemukan di jalan-jalan utama sebagian daerah wilayah DKI Jakarta hingga sepekan sejak PSBB diberlakukan. Pengendara sepeda motor masih banyak yang tidak menggunakan masker dan berboncengan. Begitu juga dengan para pedagang yang menawarkan dagangannya. Tercatat selama penerapan periode pertama penerapan PSBB di Jakarta, Polda Metro jaya mencatat ada 32.300 kendaraan yang melanggar aturan (Kompas, 2020). Jika merunut kronologi awal respon pemerintah terhadap pandemi Covid 19 maka ada empat faktor penyebab kegagalan kebijakan PSBB pemerintah Indonesia.

Pertama, lemahnya respon awal penangangan Covid-19. Hal tersebut bisa dilihat dari respon 'santai' yang ditunjukan oleh pejabat hingga menimbulkan sengkarut koordinasi diantara instansi pusat dan daerah. Krisis komunikasi yang terjadi mengakibatkan penaganan covid-19 di berbagai daerah tidak transparan dan terpadu. Kondisi tersebut terlihat dari berbagai penelitian yang menunjukan dis-trust yang ditunjukkan oleh publik kepada pemerintah. Penelitian yang dilakukan oleh INDEF menyebutkan bahwa hampir sebesar $66,3 \%$ sentimen negatif tertuju bukan hanya kepada pemerintah secara kolektif tetapi kepada Presiden dan Menteri kesehatan, atau hasil survei yang dilakukan oleh change.org yang menyebutkan 69,3\% dengan larangan jika pemerintah jangan menyepelekan masalah Covid- 
19 di awal (Pagiwati, 2020). Padahal kepercayaan dari masyarakat dapat dijadikan modal dalam membangun komunikasi yang partisipatif; yaitu komunikasi yang dilandaskan pada basis sains/pengetahuan.

Kedua, penegakan hukum yang belum optimal. Masyarakat banyak melanggar aturan dengan berbagai alasan. Pemberlakuan sanksi yang diterapkan masih banyak yang bersifat sanksi sosial dan belum diterapkan secara maksimal (Sulasih, 2020). Pemberlakuan sebuah aturan yang tanpa dibarengi oleh pengawasan dan pengawalan ketat, maka tidak akan menimbulkan efek jera bagi para pelanggarnya. Meskipun tataran hukum telah diterbitkan berbagai produk yang mengatur secara detail terkait kebijakan penanggulangan Covid-19, namun masih banyak pelanggaran yang dilakukan oleh masyarakat yang dibiarkan begitu saja. Hal yang menjadi dilematis tentu mengingat pemberlakuan hukuman akan menjadi kontraproduktif jika ditindak dengan hukuman pidana.

Ketiga, partisipasi warga masyarakat yang rendah. Partisipasi adalah faktor penentu efektivitas sebuah kebijakan. Budaya politik partisipan menjadikan individu mampu berperilaku menjaga diri dengan atau tanpa pengawasan dari aparat. Kesadaran yang tinggi dan partisipasi sukarela adalah bagian terpenting dari penanganan Covid-19 selain strategi lainnya. Hal tersebut diakui oleh Presiden Korea Selatan dan ditegaskan kembali oleh Kim Chang Beom, selaku duta besar Korea Selatan untuk Indonesia. Menurutnya, selain melakukan strategi test, trace and treat (lacak, uji dan obat), kesadaran warga menjadi hal yang penting karena di korea Selatan, setiap warga dituntut untuk patuh mengikuti aturan jaga jarak, disiplin melakukan pencegahan pribadi dan selalu mengikuti informasi. Proses pencegahan efektif dan isolasi mandiri tersebut dilakukan dengan menggunakan aplikasi selfdiagnosis dan aplikasi self-quarantin (Beom, 2020)

Keempat, massifnya perkembangan berita hoax terkait Covid-19 di tengah masyarakat. Beredar massif jika Covid-19 adalah konspirasi yang dibuat segelintir pihak demi keuntungan golongan tertentu. Lalu lalang disinformasi tersebut disebabkan oleh kemudahan akses tekhnologi dimana sebaran informasi mudah diakses oleh pengguna tanpa ada filtrasi. Kementrian Komunikasi dan Informasi (Kominfo) menemukan sebanyak 1028 isu hoax yang tersebar di berbagai platform digital (Kominfo, 2020). Hoax hadir dalam berbagai macam narasi pemberitaan berkaitan penyebab, gejala, penyebaran, hingga penyembuhan Covid-19. Hoax tentang teori konspirasi corona semakin beredar di media sosial dan menjadi pesan berantai sehingga dampak bagi perilaku masyarakat. Sikap abai dalam menjaga protokol kesehatan mebuat angka Covid-19 di Indonesia terus menanjak naik. Informasi terkait corona seharusnya berasal dari satu pintu yang terintegrasi sehingga tidak menimbulkan kesimpangsiuran di tengah masyarakat. Adapun sejauh ini penindakan yang dilakukan oleh pemerintah terhadap beredarnya issu corona masih berada dalam tindakan kuratif dengan mengajak perusahan platform digital untuk melakukan takedown (penurunan) terhadap sebaran hoax/disinformasi.

Eskalasi kasus Covid-19 masih terus terjadi dan pelanggaran-pelanggaran terhadap prinsip physical distancing pun terjadi dimana-mana. Hal ini menjadi tanda bahwa kebijakan pemerintah belum ditanggapi secara serius oleh segenap komponen masyarakat. Informasi simpang-siur tentang Covid-19 serta kegagalan memutus rantai persebaran menyebabkan tidak terjadinya perubahan sikap dan perilaku masyarakat. Untuk menyelesaikan masalah yang bersifat national threat, harus ada keputusan yang tepat dan tegas.

\section{PEMBAHASAN}

\section{Perbandingan Kebijakan Indonesia Dan India Dalam Penanganan Covid 19}

Penerapan restriksi wilayah secara ketat oleh India membawa dampak pada pengurangan penularan virus korona dan jumlah kasus yang dilaporkan. Namun efektivitas penguncian tersebut bervariasi antar wilayah dan tergantung oleh banyak faktor, termasuk variable demografis, kepadatan penduduk, dan pertemuan sosial. (Sebastian, Paul, \& 
Vilapurathu, 2020). Sementara itu, lockdown juga telah menimbulkan krisis kemanusiaan dan kekacauan baru akibat eksodus besar-besaran. Seiring berjalannya waktu, pelonggaran lockdown di India dilakukan demi menyelamatkan India dari dari jurang resesi. Hingga bulan Juni,(06/20) perekonomian India mengalami kontraksi dengan kecepatan terjal hingga 23,9\% yang terjadi akibat lockdown diberlakukan (Reuters, 2020). Setelah lockdown dilonggarkan, angka kasus terkonfirmasi covid-19 semakin meningkat di India

Indonesia sendiri memilih untuk menerapkan Pembatasan Sosial Bersakala Besar (PSBB) guna menekan laju covid-19, bukan menerapkan lockdown seperti yang dihimbau oleh WHO. Joko Widodo selaku Presiden menegaskan jika pemerintah daerah harus menerapkan kebijakan yang tidak bertentangan dengan protokol pemerintah pusat. Selain itu, Presiden membentuk satuan Gugus Tugas percepatan penangan Covid-19 guna mempermudah koordinasi pusat hingga ke daerah. Kebijakan tersebut dimulai oleh ibukota Jakarta dan diikuti oleh daerah lainnya. Jika lockdown mengharuskan penduduk untuk tidak keluar rumah sama sekali, PSBB masih memberikan ruang gerak bagi penduduk untuk melakukan aktivitas selagi tidak bertentangan dengan protokol kesehatan.

Table 1 Perbandingan Penanganan Covid-19 Yang Dilakukan Oleh India Dan Indonesia

\begin{tabular}{|c|c|c|}
\hline Jenis Penanganan & Indonesia & India \\
\hline Kasus pertama konfirmasi & 2 Maret 2020 & 30 Januari 2020 \\
\hline Jumlah kasus & 88.214 kasus/(20/7/2020) & $\begin{array}{l}1.116 .597 \\
(20 / 7 / 2020)\end{array}$ \\
\hline $\begin{array}{lll}\text { Rasio } & \text { test/Uji } & \text { Sampel } \\
\text { perhari } & & \\
\end{array}$ & $\begin{array}{l}44.543 \text { spesimen } \\
\text { (rekor terbanyak) }\end{array}$ & $\begin{array}{l}1,2 \text { juta specimen } \\
\text { (rekor terbanyak) }\end{array}$ \\
\hline Angka Fatalitas & 4.239 oraang $(20 / 7 / 2020)$ & $27.593(20 / 7 / 2020)$ \\
\hline Metode & $\begin{array}{ll}\text { Pembatasan Sosial } & \text { Skala } \\
\text { Besar (PSBB) } & \\
\end{array}$ & Lockdown \\
\hline Durasi & $\begin{array}{l}30 \text { hari } \\
\text { (tergantung kebijakan } \\
\text { daerah masing2) }\end{array}$ & $\begin{array}{l}45 \text { hari } \\
\text { (25 maret-14 April) } \\
\text { (14 April - 3 Mei) } \\
\text { (4 Mei- } 17 \mathrm{Mei}) \\
\text { (18 Mei-31 Mei) }\end{array}$ \\
\hline Medical treatment & PCR, rapid test & PCR \\
\hline Tecknologi tool & - & Aaragoya Setu \\
\hline Anggaran kesehatan & $2.99 \%$ of GDP & $3.53 \%$ of GDP $(2-17 / 2018)$ \\
\hline
\end{tabular}

Covid-19 lebih awal dikonfirmasi di India. Dengan jumlah testing yang lebih tinggi di bandingkan Indonesia, kedua negara ini mengalami kendala yang sama yakni rendahnya anggaran kesehatan. Implikasinya adalah, baik Indonesia mapun India memiliki fatalitas kesehatan yang terbatas jika dibandingkan dengan rasio jumlah populasi penduduk. Meskipun begitu, jumlah testing di Indonesia kalah jauh dengan yang sudah dilakukan oleh India. Catatan terkonfirmasi angka kasus di India mengalami lonjakan kasus setelah lockdown dilonggarkan. Hingga tulisan ini diturunkan, India menjadi negara dengan kasus konfirmasi covid-19 tertinggi di Asia.

\section{SIMPULAN}

Indonesia mengambil langkah PSBB yang dalam perjalanannya mengalami penyesuaian durasi untuk berbagai daerah. Sejumlah pelanggaran yang diakibatkan oleh rendahnya kesadaran warga masih sering ditemukan. Meskipun berhasil menekan sementara laju penyebaran Covid, PSBB dinilai tidak cukup efektif. Tantangan serupa dialami oleh India yang sama-sama memiliki populasi penduduk terbesar kedua di dunia. India memilih mengunci negara berpenduduk 1,3 miliar tersebut. Meskipun mampu menekan laju angka 
covid untuk sementara, pemberlakuan karantina wilayah secara mendadak dan minim persiapan telah menimbulkan krisis kemanusiaan. Keputusan penguncian wilayah tersebut berimbas keras pada rakyat miskin di India.

Kepemimpinan yang kuat dalam situasi krisis sangat dibutuhkan untuk memberikan arah penanganan krisis yang jelas dan menumbuhkan kepercayaan publik terhadapa sistem yang dikembangkan untuk melewati masa krisis. Dalam situasi krisis tidak semua pemimpin publik bisa menunjukan kepemimpinan memadai, yang berakibat pada tergerusnya legitimasi kepemimpinan, bahkan bisa menyebabkan krisis kepercayaan terhadap sistem. Pengalaman Indonesia di awal mewabahnya Covid-19 menunjukan salah satu beban terberat adalah politisasi pandemi di antara aktor-aktor kunci pemerintahan. Gagalnya sinergi dan kordinasi antarelemen dalam merespon ancaman pandemi akan dibayar mahal dengan krisis kemanusiaan yang mendalam.

\section{DAFTAR PUSTAKA}

Adam, A., \& Apinino, R. (2020, April 1). Lockdown India Sebabkan Kekacauan, Apa yang Terjadi? Tirto.Id. https://tirto.id/lockdown-india-sebabkan-kekacauan-apa-yang-terjadieJVG

Ambar, W., \& Mas'udi, W. (2020). Dinamika Respons Pemerintah Nasional: Krisis Kebijakan Penanganan Covid-19. dalam W. Mas'udi, \& P. S. Winarti, Tata Kelol Penangan Covid-19 di Indonesia: Kajian Awal (p. 48). Yogyakarta: UGM Press.

BBC News Indonesia. (2020, July 6). Covid-19: Sebulan usai longgarkan lockdown, India jadi negara ketiga dengan kasus terbanyak di dunia. https://www.bbc.com/indonesia/dunia-53306305

Beom, K. C. (2020, April 3). Peduli Sesama dan Bergotong Royong sebagai Kunci -. Kompas.Id. https://kompas.id/baca/opini/2020/04/03/peduli-sesama-dan-bergotongroyong-sebagai-kunci/

Berty, T. T. S. (2020, March 13). WHO Surati Jokowi, Minta RI Umumkan Darurat Nasional Virus Corona COVID-19. Liputan6.Com. https://www.liputan6.com/global/read/4201537/who-surati-jokowi-minta-ri-umumkandarurat-nasional-virus-corona-covid-19

Bhattacharjee, A., Kumar, M., \& Patel, K. K. (2021). When COVID-19 will decline in India? Prediction by combination of recovery and case load rate. Clinical Epidemiology and Global Health, 9, 17-20. https://doi.org/10.1016/j.cegh.2020.06.004

Carina, J. (2020, April 9). Berlaku 14 Hari, Penerapan PSBB di Jakarta Sampai 23 April 2020. KOMPAS.Com. https://megapolitan.kompas.com/read/2020/04/09/23332221/berlaku-14-haripenerapan-psbb-di-jakarta-sampai-23-april-2020

Colangelo, M. (2020, April 16). Deep Analysis Of Global Pandemic Data Reveals Important Insights. Forbes. https://www.forbes.com/sites/cognitiveworld/2020/04/13/covid-19complexity-demands-sophisticated-analytics-deep-analysis-of-global-pandemic-datareveals-important-insights/ 
Davidson, H., Kuo, L., \& McCurry, J. (2020, July 1). The longest holiday: parents coping with coronavirus school closures in east Asia. The Guardian. https://www.theguardian.com/world/2020/mar/03/the-longest-holiday-parents-copingwith-coronavirus-school-closures-in-east-asia

Fakhruroji, M., Tresnawaty, B., Sumadiria, H., \& Risdayah, E. (2020). Strategi komunikasi publik penanganan COVID-19 di Indonesia: Perspektif sosiologi komunikasi massa dan agama. LP2M UIN Sunan Gunung Djati.

Gettleman, J., \& Yasir, S. (2021, January 15). India's Covid Outbreak Is Now the World's Fastest-Growing. The New York Times. https://www.nytimes.com/2020/08/28/world/asia/india-coronavirus.html

Global Democracy Ranking. (2014). Democracy Ranking 2015. Democracy Ranking. http://democracyranking.org/wordpress/rank/democracy-ranking-2015/.

HT Correspondent. (2020, July 19). Coronavirus in India: Highest single-day spike of 40k pushes count past 1.1 million. Hindustan Times. https://www.hindustantimes.com/india-news/highest-single-day-spike-of-40k-pushescount-past-1-1-mn/story-eTLEIMrU8idNSMuxiXmVYK.html

International Growth Center. (2020, May 14). Webinar: The impact of COVID-19 on informal and migrant workers in India[Video]. YouTube. https://www.youtube.com/watch?v=NcVAyxFSt8M

Kikon, D. (2021, January 7). A long way from home. Pursuit. https://pursuit.unimelb.edu.au/articles/a-long-way-from-home

Kluth, A. (2020, March 31). From Orban to Kaczynski, Wannabe Autocrats Love the Pandemic. Washington Post. https://www.washingtonpost.com/business/from-orban-tokaczynski-wannabe-autocrats-love-the-pandemic/2020/03/30/4dd7a89a-72a7-11eaad9b-254ec99993bc_story.html

Kominfo. (2020). Kominfo Mencatat Sebanyak 1.028 Hoaks Tersebar terkait COVID-19. Website Resmi Kementerian Komunikasi Dan Informatika RI. https://kominfo.go.id/content/detail/28536/kominfo-mencatat-sebanyak-1028-hoakstersebar-terkait-covid-19/0/sorotan_media

Kompas. (2020, April 27). Jumlah Pelanggar PSBB Jakarta Periode Awal Capai 32.300 Kendaraan. KOMPAS.Com. https://otomotif.kompas.com/read/2020/04/27/070200315/jumlah-pelanggar-psbbjakarta-periode-awal-capai-32.300-kendaraan

Lal, D. M., \& Pawar, S. D. (2011). Effect of urbanization on lightning over four metropolitan cities of India. Atmospheric Environment, 45(1), 191-196. https://doi.org/10.1016/j.atmosenv.2010.09.027

Laxminarayan, R., Wahl, B., Dudala, S. R., Gopal, K., Mohan B, C., Neelima, S., Jawahar Reddy, K. S., Radhakrishnan, J., \& Lewnard, J. A. (2020). Epidemiology and transmission dynamics of COVID-19 in two Indian states. Science, 370(6517), 691697. https://doi.org/10.1126/science.abd7672 
Mas'udi, W., \& Winarti, P. S. 2020. Tata Kelola Penanganan Covid-19 Di Indonesia Kajian Awal. Yogyakarta: Gajah Mada University Perss.

Muradi, G. F. (2016). DEMOKRASI CIVIL SOCIETY DI INDONESIA DAN INDIA: SEBUAH PERBANDINGAN. Jurnal Wacana Politik, 1(2). https://doi.org/10.24198/jwp.v1i2.11061

Najwa Shihab. (2020, April 22). Jokowi Diuji Pandemi: Didesak Mundur, Menkes Terawan Dipuji Jokowi (Part 1) | Mata Najwa[Video]. YouTube. https://www.youtube.com/watch?v=JFHHzLixfXA

Nursastri, S. A. (2020, April 10). Pakar Peringatkan, Indonesia dan India Berpotensi Jadi Episenter Baru Covid-19. KOMPAS.Com. https://www.kompas.com/sains/read/2020/04/10/180200123/pakar-peringatkanindonesia-dan-india-berpotensi-jadi-episenter-baru-covid

Pagiwati, Rosi Tri. (2020, July 30). Webinar FISIP UI 2020 - Seri 01 : Komunikasi Publik Pemerintah di Masa Pandemi Covid-19[Video]. YouTube. https://www.youtube.com/watch?v=0vwFmk9eHcI

Pai, Chintamani, Bhaskar, A. \& Rawoot V. 2020. "Investigating the Dynamics of COVID-19 Pandemic in India under Lockdown." Chaos, Solitons and Fractals 138: 109988. https://doi.org/10.1016/j.chaos.2020.109988

Paital, B., Das, K., \& Parida, S. K. (2020, September 1). Investigating the dynamics of COVID-19 pandemic in India under lockdown. ScienceDirect. https://linkinghub.elsevier.com/retrieve/pii/S0960077920303878

Reuters. (2020, September 4). GDP contracts by record $23.9 \%$ in Q1. Factly. https://factly.forumias.com/gdp-contracts-by-record-23-9-in-q1/

Saha, J., Barman, B., \& Chouhan, P. (2020). Lockdown for COVID-19 and its impact on community mobility in India: An analysis of the COVID-19 Community Mobility Reports, 2020. Children and Youth Services Review, 116, 105160. https://doi.org/10.1016/j.childyouth.2020.105160

Sebastian, S., Paul, A., Joby, J., Saijan, S., Joseph, J., \& Kunjumon, J. (2020). Impact of Lockdown in India: A Case Study Comparing Karnataka with an International Model. Kesmas-National Public Health Journal. 15(2): 93-98.

Shereen, M. A., Khan, S., Kazmi, A., Bashir, N., \& Siddique, R. (2020). COVID-19 infection: Origin, transmission, and characteristics of human coronaviruses. Journal of Advanced Research, 24, 91-98. https://doi.org/10.1016/j.jare.2020.03.005

Sulasih, E. S. (2020). Ketidakefektifan Penerapan Pembatasan Sosial Berskala Besar (PSBB) di Daerah Khusus Ibukota Jakarta. Binamulia Hukum, 9(1), 67-82. https://doi.org/10.37893/jbh.v9i1.104

Syaodih, S. N. 2007. Metode Penelitian Pendidikan. Bandung: Rosdakarya. 
Tempo. (2020, April 7). Pembatasan Sosial untuk Hentikan Penularan Covid-19. https://nasional.tempo.co/read/1328644/pembatasan-sosial-untuk-hentikan-penularancovid-19

WHO. 2020. 14 World Health Organization Coronavirus Disease 2019 (COVID-19) Situation Report - 42 Data as Reported by 10 AM CET 02 March $2020 \mathrm{H}$. https://www.who.int/docs/default-source/coronaviruse/situation-reports/20200302sitrep-42-covid-19.pdf?sfvrsn=224c1add_2. 